\title{
Protective Effect of Prunus Dulcis against Acetylsalicylic Acid Injury on Gastric Parietal Cells: An Experimental Study
} \author{
FAIZA IRSHAD ${ }^{5}$, MUHAMMAD AFZAL KHAN ${ }^{5}$, TALHA LAIQUE $6^{*}$ \\ ${ }^{1}$ Department of Anatomy, CMH Kharian Medical College, Kharian, Pakistan \\ ${ }^{2}$ Department of Anatomy, Watim Medical College, Rawalpindi, Pakistan \\ ${ }^{3}$ Department of Anatomy, Mohterma Benazir Bhutto Shaheed Medical College, Mirpur, AJK \\ ${ }^{4}$ Department of Medicine, CMH Kharian Medical College, Kharian, Pakistan \\ ${ }^{5}$ Department of Anatomy, M. Islam Medical College, Gujranwala, Pakistan \\ ${ }^{6}$ Department of Pharmacology, Allama lqbal Medical College, Lahore-Pakistan \\ Correspondence to Dr. Talha Laique, Email: talhalaique51@gmail.com Tel:+92-331-0346682.
}

MUHAMMAD SAAD ABDULLAH ${ }^{1}$, KISHWAR NAHID ${ }^{2}$, FAREEHA MUSHTAQ ${ }^{3}$, ANEEQA CHUGHTAI ${ }^{1}$, SABA IZHAR ${ }^{4}$,

\begin{abstract}
Background: Acetylsalicylic acid is in common clinical use but has the side effect of causing gastric mucosal erosions and selective injury to parietal cells.

Aim: To explore if prior treatment with Prunus dulcis (almond) had a protective effect against acetylsalicylic acid induced injury.

Study design: Experimental study.

Methodology: Albino mice weighing 30 to 40 grams were given two drops of almond oil without peel and $300 \mathrm{mg}$ of finely ground whole almond kernel by oral gavage for sixty days followed by $400 \mathrm{mg} / \mathrm{kg}$ body weight of acetylsalicylic acid orally. Gastric mucosal damage was observed and recorded as ulcer index. The number of parietal cells/ sq. micrometer and area of parietal cells were observed and recorded under microscope in formalin fixed $\mathrm{H}$ and $\mathrm{E}$ stained sections. Data analyzed by SPSS $22.0 \mathrm{v}$.

Results: Mucosal damage, distortion of gastric glands and damage to parietal cells was pronounced in the positive control animals. The number of surviving parietal cells after acetylsalicylic acid insult in animals given almond oil was significantly higher when compared with positive control animals $(p<0.001)$ and even better in animals receiving whole ground almond kernel. The area of parietal cells was also similarly larger in the treated animals.

Conclusion: This study concluded Prunus dulcis offers protection against acute gastric mucosal injury and damage to the gastric parietal cells caused by acetylsalicylic acid in mice.

Keywords: Prunus Dulcis, Parietal Cells, Gastric Erosions and Acetylsalicylic Acid.
\end{abstract}

\section{INTRODUCTION}

Acetylsalicylic acid commonly known as Aspirin along with other NSAIDS is widely used in clinical practice as an analgesic and anti-inflammatory agent and for a variety of various affections and is easily available over the counter. One of the very serious side effects of this drug is gastric mucosal injury in the form of erosions or ulcers and damage to parietal cells ${ }^{1}$. Quite a few orthodox pharmaceutical preparations such as anticholinergic drugs, $\mathrm{H}_{2}$-receptor antagonists, antacids, and proton-pump inhibitors have been used to manage the injury. These pharmaceutical products, however, have their own set of adverse effects.

In recent years, there has been growing interest in alternative therapies especially from plant sources due to their perceived lower side effects, ease of access and affordability $^{2}$. The quest to explore plant products that may have potential to successfully counter the ulcerogenic effects of NSAIDS has been sparse and scanty².

Prunus dulcis (Almond) is a native tree in Middle East and Asia. Kernel is the edible part consumed as such or used in cooking. Almond oil is widely used in cosmetic, pharmaceutical and culinary preparations. Plants, including almond have been shown to have promise for the treatment of gastroduodenal ulcer with minimum side effects $^{3,4}$.

Received on 05-02-2021

Accepted on 13-06-2021
The objective of the study was to explore whether Prunus dulcis provided protection against acetylsalicylic acid induced gastric mucosal damage to parietal cells in mice.

\section{METHODOLOGY}

It was a laboratory based experimental study carried out at the Army Medical College (AMC), in collaboration with National Institute of Health $(\mathrm{NIH})$ and Armed Force Institute of Pathology (AFIP), Rawalpindi after the approval of the Ethical Committee on animal experiments of the AMC. Forty healthy adult male and non-pregnant female BALB/c mice weighing 30 to 40 grams with an age of 9-11 weeks were included in the study. Male and female mice were kept separately. A solution of pure analytical reagent grade acetylsalicylic acid was prepared so that $0.83 \mathrm{ml}$ contained a dose equaling $400 \mathrm{mg} / \mathrm{kg}$ body weight. Almond oil was extracted after removing the kernel peel. Whole kernels with peel were finely ground. Animals were randomly divided into four groups of ten animals each and treated as follows:

- Group A: Animals remained on regular diet for 60 days and served as Negative Control.

- Group B: Animals remained on regular diet for 60 days but remained fasting for the last 24 hours and received orally $0.83 \mathrm{ml}$ of acetylsalicylic acid on the last day of the experiment to serve as Positive Control. 
Animals were sacrificed after five hours of acetylsalicylic acid treatment.

- Group C: Animals remained on regular diet for 60 days and received two drops of almond oil by oral gavage once a day. The animals remained fasting for the last 24 hours, were given $0.83 \mathrm{ml}$ of acetylsalicylic acid solution via oral gavage and sacrificed after five hours.

- Group D: Animals remained on regular diet for 60 days and received $300 \mathrm{mg}$ of finely ground whole almond kernel once a day. On the last day the animals were given $0.83 \mathrm{ml}$ of acetylsalicylic acid solution via oral gavage and sacrificed after five hours.

In each animal the stomach was examined by naked eye and under dissecting microscope for any damage. A longitudinal slice was removed for paraffin sectioning and $\mathrm{H}$ and $E$ staining. Ulcer score was rendered as 0-3 according to the classification by Desai ${ }^{5}$. Gastric mucosal damage was observed and recorded as ulcer index. The number of parietal cells/ sq. micrometer and area of parietal cells were observed and recorded under microscope in formalin fixed $\mathrm{H}$ and $\mathrm{E}$ stained sections. Sim ilarly three well-oriented glands were selected in ten fields for assessment of the parietal cell area which was calculated by using a morphometric computer software Image $\mathrm{J}$ v1.486.

Statistical analysis: Data analyzed by SPSS $22.0 \mathrm{v}$. Measurement tool 'Freehand selection' was selected and the area to be measured was outlined and the measurements recorded. The final reading was noted as the mean of areas of parietal cells per specimen. Results were tabulated and statistical analysis and comparisons among various groups carried out. Significance was considered at $95 \%$ confidence interval having $p$-value $<0.05$.
The severity of gastric mucosal damage and the ulcer index were given in Table-1 and Figure-1. Results for number and area of parietal cells were given in table-2 in present study. Results for comparison of $P$-Values of number \& area of parietal cells amongst different groups were given in table-3. Histological comparison of changes amongst different groups was presented in Figure-2.

Figure 1: Depicting normal gastric mucosa in group $A$ and mucosal damage and ulceration in group B treated with acetylsalicylic acid.

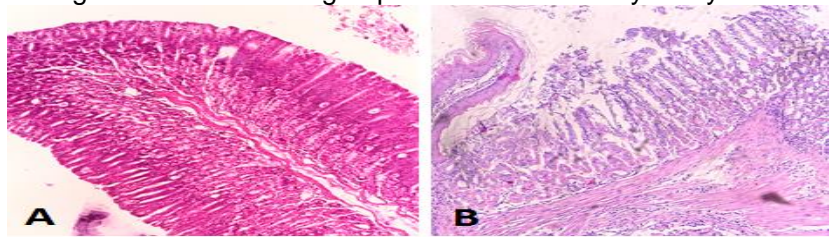

Figure 2: Depicting histological comparison of changes in the gastric mucosa.

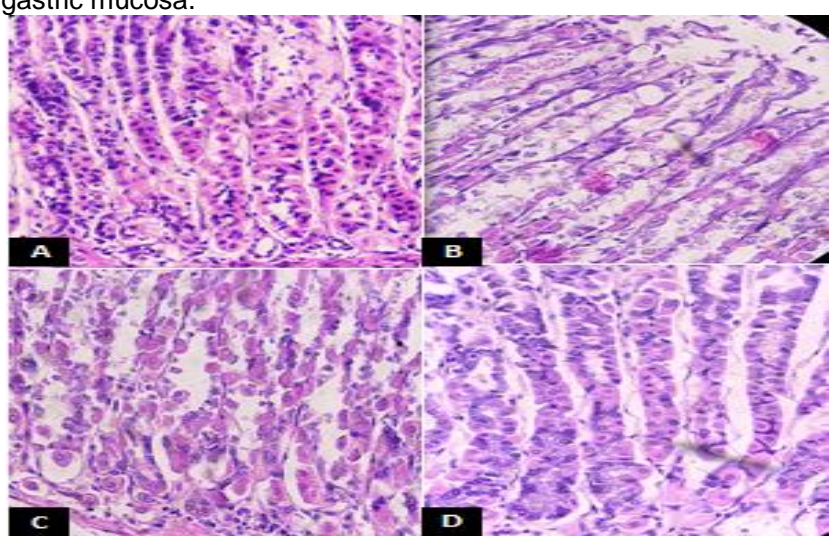

\section{RESULTS}

Table 1: Severity of Gastric Ulcer and Ulcer Index Between Groups

\begin{tabular}{|c|c|c|c|c|c|}
\hline & $\begin{array}{l}\text { Group A } \\
\text { Control } \\
\text { Mean } \pm S D(n=10)\end{array}$ & $\begin{array}{l}\text { Group B } \\
\text { ASA group } \\
\text { Mean } \pm S D(n=10)\end{array}$ & $\begin{array}{l}\text { Group C } \\
\text { ASA plus Almond oil, } \\
\text { Mean } \pm S D(n=10)\end{array}$ & $\begin{array}{l}\text { Group D } \\
\text { ASA plus Finely Granular Almonds } \\
\text { Mean } \pm S D(n=10)\end{array}$ & $\begin{array}{l}\mathbf{B} \text { vs } \mathbf{C} \text { and } \mathbf{D} \\
p \text { value }\end{array}$ \\
\hline Severity of gastric ulcer & $0.00 \pm 0.00$ & $1.00 \pm 0.00$ & $0.30 \pm 0.48$ & $0.20 \pm 0.41$ & $<0.001^{*}$ \\
\hline Ulcer Index & $0.00 \pm 0.00$ & $3.00 \pm 0.00$ & $0.90 \pm 0.00$ & $0.30 \pm 0.00$ & $<0.001^{*}$ \\
\hline
\end{tabular}

${ }^{*}$ Statistically significant

Table 2: Number and Area of Parietal Cells and statistical comparison Between Groups

\begin{tabular}{|l|l|l|l|l|}
\hline & $\begin{array}{l}\text { Group A Control } \\
\text { Mean } \pm \text { SD } \\
(\mathrm{n}=10)\end{array}$ & $\begin{array}{l}\text { Group B - } \\
\text { ASA group } \\
\text { Mean } \pm \text { SD }(\mathrm{n}=10)\end{array}$ & $\begin{array}{l}\text { Group C } \\
\text { ASA plus Almond oil } \\
\text { Mean } \pm S D(n=10)\end{array}$ & $\begin{array}{l}\text { Group D - } \\
\text { ASA plus Finely Granular } \\
\text { Almonds Mean } \pm S D(n=10)\end{array}$ \\
\hline Number of parietal cells & $24.93 \pm 2.78$ & $13.73 \pm 2.51$ & $23.30 \pm 1.92$ & $24.56 \pm 2.05$ \\
\hline Area of parietal cells $\left(\mu \mathrm{m}^{2}\right)$ & $12.92 \pm 2.52$ & $10.16 \pm 3.03$ & $13.52 \pm 2.64$ & $12.96 \pm 1.45$ \\
\hline
\end{tabular}

**Highly significant * Significant

Table 3: Comparison of $P$-Values of number \& area of parietal cells amongst groups

\begin{tabular}{|c|c|c|c|c|c|c|}
\hline & $\begin{array}{l}\text { Group A vs } \\
\text { Group B }\end{array}$ & $\begin{array}{l}\text { Group A vs } \\
\text { Group C }\end{array}$ & $\begin{array}{l}\text { Group A vs } \\
\text { Group D }\end{array}$ & $\begin{array}{l}\text { Group B vs } \\
\text { Group C }\end{array}$ & $\begin{array}{l}\text { Group B vs } \\
\text { Group D }\end{array}$ & $\begin{array}{l}\text { Group C vs } \\
\text { Group D }\end{array}$ \\
\hline Number of parietal cells & $<0.001^{\star *}$ & 0.985 & 0.985 & $<0.001^{\star *}$ & $<0.001^{\star *}$ & 0.897 \\
\hline Area of parietal cells & 0.080 & 0.948 & 1.000 & $0.023^{*}$ & 0.018 & 0.958 \\
\hline
\end{tabular}

${ }^{* \star}$ Highly significant ${ }^{*}$ Significant

\section{DISCUSSION}

Acetylsalicylic acid in the dose as described given to the positive control group B animals in this study successfully produced gastric ulceration with an ulcer index of 3.0 and was in accordance with observations of previous workers $^{7,8}$.
It has been described that gastric mucosal injury is produced by reduced production of cyclooxygenase and prostaglandins ${ }^{1,9}$. Acetylsalicylic acid is a strong inhibitor of COX-1 which maintains mucosal integrity ${ }^{10}$. It has also been documented that acetylsalicylic acid directly disrupts the gastric mucosa not only by decreasing the production 
of prostaglandins but also by reducing the gastric mucosal blood flow ${ }^{9-11}$.

Microscopic observations in this study revealed not only loss of glandular architecture and damage to the surface epithelium but also loss and injury to the parietal cells in group B. Group C and D had the regular arrangement resembling group $A$ with large patches of well-preserved parietal cells. A remarkable decrease in the area of parietal cells was observed in group B while group $C$ and $D$ showed an increasing trend towards normal. Statistical comparison between $B$ vs $C$ and $D$ was found to be significant with $\mathrm{p}<0.023$ and $\mathrm{p}<0.018$ respectively. Whereas the parietal cells in group $B$ were shrunken and distorted in shape with vacuoles in cytoplasm and displaced nucleus they had normal appearance in well preserved gastric glands in group $C$ and $D$ resembling those in group $A$.

The number of parietal cells was found to be remarkably reduced in the positive control group $B$ (13.73 \pm 2.51$)$ as compared to the negative control group $A$ (24.93 \pm 2.78$)$; the statistical difference being highly significant $(p<0.001)$. Similar findings have been described in a previous study which proposed that autolysis was the reason for reduced number of parietal cells after acetylsalicylic acid insult ${ }^{9}$. The number was much higher reaching closer to normal in group $C(23.30 \pm 1.92)$ treated with almond oil while in group $D$ treated with ground whole kernel it was even better (24.56 \pm 2.05$)$ and almost as good as normal. While group $C$ and $D$ had a highly significant difference when compared with group $B(p<0.001)$ the statistical difference from group $A$ was not significant. The comparison between group C and D was also not significant.

The decrease in the size and number of parietal cells as observed in the study was because of cell autolysis as described by earlier workers. The acetylsalicylic acid getting trapped inside these cells leads to increased acid secretion along with an augmented pepsinogen activity leading to cellular damage and release of hydrolytic enzymes and thus resulting in parietal cell autolysis and decrease in size ${ }^{12-14}$.

Preservation of gastric mucosal architecture along with a remarkable survival of the parietal cells after acetylsalicylic acid injury in animals treated with almond oil extracted without peel and more pronounced in those treated with whole ground kernel strongly illustrate that prior treatment of animals with Prunus dulcis had a powerful protective effect on the gastric mucosa against acetylsalicylic acid insult.

Better preservation of gastric mucosa generally and parietal cells in particular in group $D$ as compared to group $\mathrm{C}$ indicate that kernel peel seems to have a supplimentary supportive role in protecting against acetylsalicylic acid injury. Similar findings have been described in an in-vivo experimental study in the intestine ${ }^{15}$. This outcome in the current study is supported by the fact that peel of Prunus dulcis kernel possesses potential prebiotic and anti-oxidant properties ${ }^{15,16}$

Not withstanding these promising results of the study, however, more research is warranted to find the optimum dose and the active ingredients in Prunus dulcis kernel operative as the protective agents and to elucidate their mechanism of action. It would also be worthwhile to study the protecting effect on gastric mucosal injury caused by NSAIDS other than acetylsalicylic acid. Further exploration of the gastroprotective effects of Prunus dulcis can provide safer and cheaper alternative to pharmacological gastroprotective agents and help avoid their deleterious side effects.

Limitations: Present study had number of limitations like small sample size, financial constrains and limited resources.

\section{CONCLUSION}

This study concluded that Prunus Dulcis offers protection against acute gastric mucosal injury and damage to the gastric parietal cells caused by acetylsalicylic acid in mice.

Author's contribution: MSA: Conceptualized the study, analyzed the data, and formulated the initial draft, KN \& FM: Contributed to the histomorphological evaluation, AC \& SI: Contributed to the analysis of data and proofread the draft, FI \& MAK: Contributed to data collection, TL: Contributed to the proof reading the manuscript for intellectual content

Acknowledgements: I am thankful to Allah and my colleagues who made it possible for me.

Conflict of interest: None

Funding: None

\section{REFERENCES}

1. Koizumi, S., Odashima, M., Otaka, M., Jin, M., Linden, J., Watanabe, S. \& Ohnishi, H. 2009. Attenuation of gastric mucosal inflammation induced by indomethacin through activation of the A2A adenosine receptor in rats. J Gastroenterol, 44, 419-25

2. Gupta A., Sharma R., Sharma S. (2020) Almond. In: Nayik G.A., Gull A. (eds.) Antioxidants in Vegetables and Nuts - Properties and Health Benefits Springer, Singapore

3. Alkofahi, A. \& Atta, A. H. 1999. Pharmacological screening of the antiulcerogenic effects of some Jordanian medicinal plants in rats. J. Ethnopharmacol., 67, 341-345

4. Schmeda-Hirschmann, G. \& Yesilada, E. 2005. Traditional medicine and gastroprotective crude drugs. J Ethnopharmacol, 100, 61-6

5. Desai, J. K., Goyal, R. K. \& Parmar, N. S. 1999. Characterization of dopamine receptor subtypes involved in experimentally induced gastric and duodenal ulcers in rats. J Pharm Pharmacol, 51, 187-92.

6. Schneider, C. A., Rasband, W. S. \& Eliceiri, K. W. 2012. NIH Image to ImageJ: 25 years of image analysis. Nat Methods, 9, 671-5.

7. 7Farrell, J. J., Taupin, D., Koh, T. J., Chen, D., Zhao, C.-M., Podolsky, D. K. \& Wang, T. C. 2002. TFF2/SP-deficient mice show decreased gastric proliferation, increased acid secretion, and increased susceptibility to NSAID injury. J Clin Invest, 109, 193-242

8. Ajaikumar, K. B., Asheef, M., Babu, B. H. \& Padikkala, J. 2005. The inhibition of gastric mucosal injury by Punicagranatum $L$. (pomegranate) methanolic extract. J Ethnopharmacol, 96, 171-6

9. Andrews, F. J., Malcontenti-Wilson, C. \& O'Brien, P. E. 1994. Effect of nonsteroidal anti-inflammatory drugs on LFA-1 and ICAM-1 expression in gastric mucosa. Am J Physiol, 266, G657-64

10. Meade, E. A., Smith, W. L. \& DeWitt, D. L. 1993. Differential inhibition of prostaglandin endoperoxide synthase (cyclooxygenase) isozymes by aspirin and other non-steroidal anti-inflammatory drugs. $J$ Biol Chem, 268, 6610-4

11. Wang, G. Z Huang, G. P Yin G. L Zhou, G., Guo, C. J., Xie, C. G., Jia, B. B. \& Wang, J. F. 2007. Aspirin can elicit the recurrence of gastric ulcer induced with acetic acid in rats. Cell Physiol Biochem, 20, 205-212

12. Laine, L., Takeuchi, K. \& Tarnawski, A. 2008. Gastric mucosal defense and cytoprotection: bench to bedside. Gastroenterology, 135, 41-61

13. Wallace, J. L. 2008. Prostaglandins, NSAIDs, and gastric mucosal protection: why doesn't the stomach digest itself? Physiol Rev, 88, 1547-1565

14. Wallace, J. L. 2000. How do NSAIDs cause ulcer disease? Best Pract Res Clin Gastroenterol, 14, 147-159

15. Liu, Z., Lin, X., Huang, G., Zhang, W., Rao, P. \& Ni, L. 2014. Prebiotic effects of almonds and almond skins on intestinal microbiota in healthy adult humans. Anaerobe, 26, 1-6

16. Mandalari, G., Tomaino, A., Arcoraci, T., Martorana, M., Turco, V. L., Cacciola, F., Rich, G. T., Bisignano, C., Saija, A., Dugo, P., Cross, K. L., Parker, M. L., Waldron, K. W. \& Wickham, M. S. J. 2010 Characterization of polyphenols, lipids and dietary fibre from almond skins (Amygdalus communis L.). J Food Compos Anal, 23, 166-174. 